\title{
THE CHRONOLOGY OF A SAD HISTORICAL MISJUDGEMENT: THE INTRODUCTIONS OF RABBITS AND FERRETS IN NINETEENTH- CENTURY NEW ZEALAND
}

CAROLYN M. KING

\section{Abstract}

During the second half of the nineteenth century, rabbit damage to pastoral runs was threatening to bring about a serious economic crisis in the southern South Island of New Zealand. The obvious solution was to import thousands of the rabbits' 'natural enemies'-starting with ferrets-in the hope they would keep the rabbits under control. This article reviews the arguments surrounding this decision, and describes the persons most actively involved, their reasoning and their actions, compiled from contemporary documents and reports, many unpublished. The introduction of ferrets proceeded despite repeated local and international warnings, but ferrets could not remove enough rabbits to prevent the continuing damage to sheep pastures. Contemporary ecologists often wonder why such reckless decisions were made, but this new analysis of the historic details illustrates how well-meant and apparently reasonable environmental management actions can precipitate a cascade of unintended and undesirable consequences.

Keywords: pastoralism, colonial government, environmental history, rabbit pest, ferret, New Zealand

\section{Introduction}

The history of the arrival and impact of rabbits in New Zealand has become one of the best-known examples of well-intentioned acclimatisation gone wrong. ${ }^{1}$ Enterprising settlers first released wild rabbits in the reasonable hope of establishing a source of fresh meat and shooting sport, but without any way to anticipate the

1 J. A. Gibb and J. M. Williams, 'The rabbit in New Zealand', in The European Rabbit: the History and Biology of a Successful Colonizer, ed. H. V. Thompson and C. M. King (Oxford: Oxford University Press, 1994), 158-204. 
unexpected results. The previous experience of the colonists gave them no hint that rabbit populations might behave differently in New Zealand from the way they did in Britain at the time. They were surprised to see that, from the early to mid-1870s, burrowing and pasture damage by rabbits was beginning to cause serious reductions in sheep numbers, wool clip and lambing percentages associated with malnutrition of the breeding ewes. The consequent decline in the value of pastoral land set back by decades the development of pastoralism, the dominant source of income of the young colony. ${ }^{2}$

Apparently rational decisions made by those who attempted to control the rabbit plague by introducing 'the rabbits' natural enemies' simply compounded the problem, but for different, less forgivable reasons. They did not act in ignorance, but against vehement and well-informed objections that predicted all too accurately the risk of irreversible damage to New Zealand's endemic fauna. ${ }^{3}$ Until now, there has never been a comprehensive review of the origins and numbers of the ferrets imported, or the methods by which they were collected and transported, and many existing accounts are inaccurate or incomplete. By contrast, historical documents preserve, in often startling detail, the way that crucial decisions were made during this unfolding crisis.

The rabbit invasion that began in the late 1860s badly shook the newly developed pastoral agriculture establishment and its associated clients. The Colonial Office and successive ministers considered the problem only in terms of how to save the wool industry by finding more and better ways to kill rabbits, especially if that could be done free of charge by natural enemies. They reasoned that the balance of nature had been artificially disturbed, so some compensation would be needed. Colonial officials had no way to understand why natural enemies could not attain the effect required over the long term and at the landscape scale required. ${ }^{4}$ Semi-domestic ferrets, known and efficient rabbit-killers, easy to handle and breed, and already present in Australia, were the most obvious natural enemy of the rabbit to try first.

2 S. Hodgkinson, 'Report of the Rabbit Nuisance Committee', Appendix to the Journals of the House of Representatives [henceforth AJHR] I-5 (Wellington: George Didsbury, Government Printer, 1876); J. L. C. Richardson and W. H. Pearson, 'The Rabbit Nuisance in Southland', AJHR H-10 (1876); P. Holland and G. Figgins, 'Environmental disturbance triggering infestations of gorse, rabbits and thistles in southern New Zealand: 1850 to 1980', International Review of Environmental History 1 (2015): 41-79.

3 W. L. Buller, 'On the proposed introduction of the polecat into New Zealand', Transactions \& Proceedings of the New Zealand Institute 9 (1877): 634-5.

4 G. Norbury, 'Mythbusters: can predators control rabbits in New Zealand?', Kararehe Kino 18 (2011): 22; G. Norbury and B. Reddiex, 'European rabbit', in Handbook of New Zealand mammals, 2nd ed., ed. C. M. King (Melbourne: Oxford University Press, 2005), 131-50. 


\section{The location and size of the problem}

Rabbits prefer a dry climate and soft, sandy soils that are easy to burrow in. Hence the 'rabbit problem' in New Zealand was largely confined to the grassy, low-rainfall eastern areas on both main islands, mapped by Peter Holland and Guil Figgins (Figure 1). These were the areas first settled by pastoralists from the 1850 s onwards, who grazed large flocks of sheep on runs (blocks of Crown-owned grassland) leased from the government under licence.

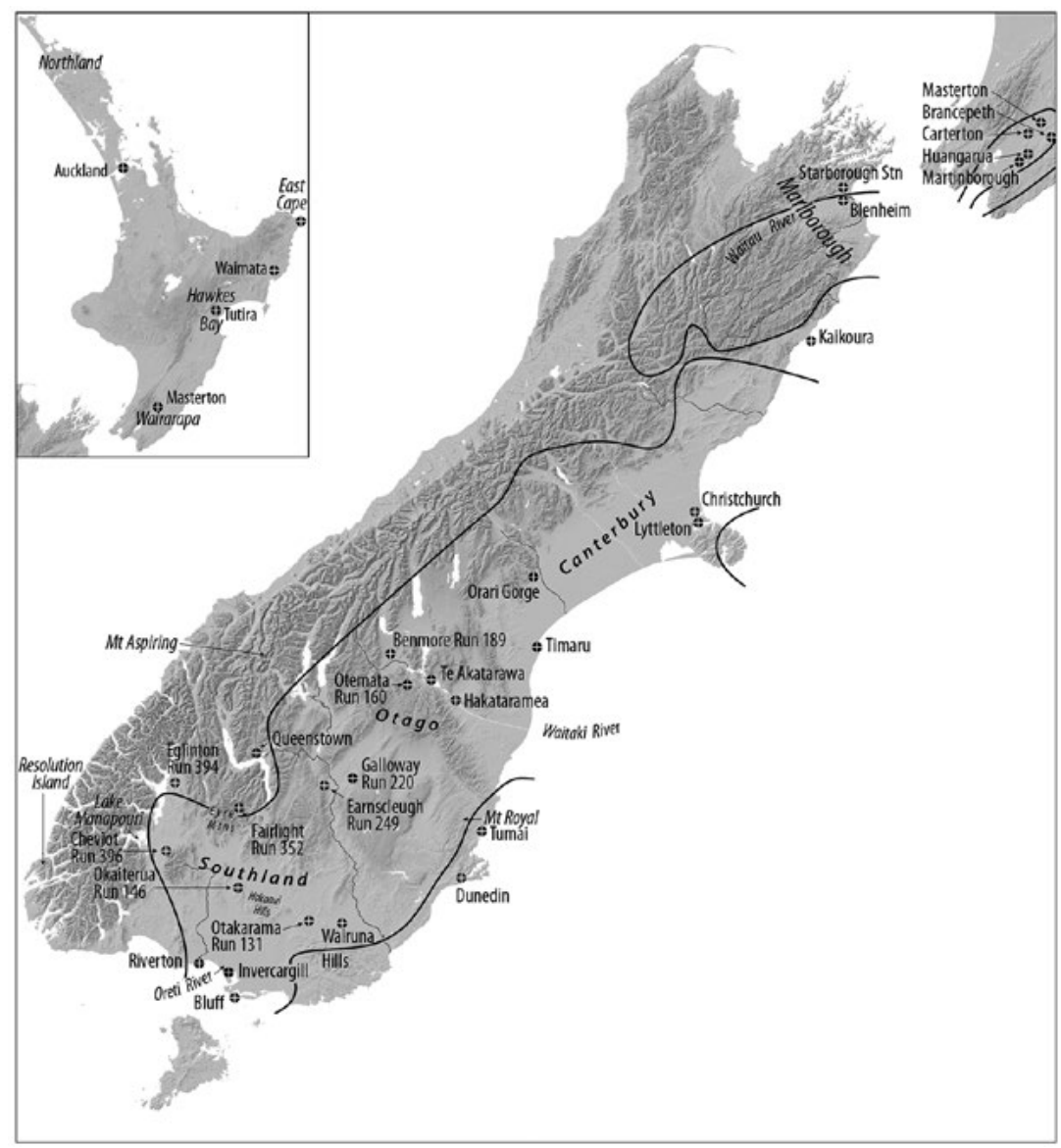

Figure 1: Locations of places mentioned in the text. Dark lines enclose the extent of open country, as defined by Holland and Figgins, ${ }^{5}$ that is, the main area covered by pastoral runs and the favoured habitat for rabbits. For names, numbers and further descriptions of runs in Otago and Southland, see Pinney ${ }^{6}$ and Sinclair. ${ }^{7}$

Source: The author. Cartography: Max Oulton.

5 Holland and Figgins, 'Environmental disturbance triggering infestations', 41-79.

R. Pinney, Early Northern Otago Runs (Auckland: Collins, 1981).

7 J. G. Sinclair, 'The Early Pastoral Runs of Otago and Southland', (Dunedin: Hocken Library, 2003). 
By 1882 , more than 1,000 runs were established, of which all but 26 were in the South Island. ${ }^{8}$ Three-quarters of the 1.3 million acres $(526,091$ ha) of pastoral land occupied in 1882, and two-thirds of the runs, lay in Otago and Canterbury. These two provinces also supplied more than half of the national wool clip for export. Hence the runholders in those areas, especially those in Otago, had a disproportionately large influence on the colonial secretary's policy concerning rabbits. Many of them were members of the Squatters' Club in Dunedin, the local equivalent of the best gentlemen's clubs in London, with the same connections with the levers of power. ${ }^{9}$

In the South Island, there were two separate centres of rabbit invasion at opposite ends of the island: Marlborough-Kaikoura in the north, and Southland-Otago in the south. In Southland and Otago, rabbit damage was already becoming locally severe by 1875 . Most of Canterbury was still free of rabbits in late 1883 , but the Canterbury runholders feared invasion from both directions. ${ }^{10}$ In the North Island, the first populations of rabbits to reach very large numbers were confined to the Wairarapa and Hawkes Bay.

In 1883, runholder Charles de Vere Teschemaker attempted to account for the full scale of the damage done to the economy of the colony by rabbits. The logic of his estimate is worth considering in full:

The public pastoral estate of Otago and Southland alone consists of some 8,000,000 acres $[3,237,485 \mathrm{ha}]$. In 1873 , this land was worth from $5 \mathrm{~s}$ to 40 s an acre, say an average of $15 \mathrm{~s}$, and would have been readily purchased at that price. Total value, $£ 6,000,000$. Today [29 September 1883], solely on account of the rabbit, the public estate of Otago and Southland has depreciated fully 50 per cent ... our loss ... so far as the capital value of the country is concerned, up to the present amounts to $£ 3,000,000$; [plus] an annual loss [of income from reductions in lambing percentages and wool clip] of $£ 1,700,000 .{ }^{11}$

Throughout the 1880 s, the need to find a solution to the rabbit problem became ever more pressing. The Oamaru Mail reported the rabbit pest was 'developing into a difficulty quite as large and stubborn as any with which the colony is called upon to deal. Nobody seems to really know how to face it'. The newspaper cited a report by the Commissioner for Crown Lands in Canterbury, who found that the rabbits swarming just south of the border with Otago were eating the country bare,

8 Registrar-General's Office, Statistics of the Colony of New Zealand for the years 1870 to 1899 [Blue Books] (Wellington: Government Printer, 1870-99).

9 F. R. J. Sinclair, 'High Street Quaking: A history of Dunedin's "Inner Circle"' (PhD diss., University of Otago, 1996).

10 R. M. Burdon, High Country: The evolution of a New Zealand sheep farm (Auckland: Whitcombe and Tombs, 1938).

11 C. de V. Teschemaker, 'The Rabbit Nuisance', (Nelson: [s.n.], 1883). A copy is held in the Sir George Grey Special Collections, Auckland Central City Library, at 636.9 T33. 
and were now 'menacing Canterbury ... but whether poison, or ferrets, stoats, and weasles, or men and dogs, or all of them, should be employed is a matter on which experts only are capable of judging' ${ }^{12}$

\section{Natural enemies of the rabbit}

Ferrets are semi-domesticated animals with a long history of artificial breeding, which made them easy to tame and handle, either as a pet or as a trained working companion for a rabbit-catcher, but unused to living independently of human care. The use and management of ferrets to control and harvest rabbits was a wellestablished rural skill, widely practised in Britain ${ }^{13}$ and easily imported into New Zealand with experienced immigrants. The ferrets themselves were bad travellers, but local ferret-breeding stud farms could be easily established to supply the accelerating demand from New Zealand landholders. Over at least 50 years after 1870, tens of thousands of ferrets were bred and released on rabbit-damaged pastoral lands.

Ferrets are specialist predators of small to mid-sized rodents and rabbits. Their long, thin bodies and short legs give them a smooth tubular shape that allows them to move easily through rabbit burrows. They have sharp, triangular faces, small, rounded ears folded back against the head, and a short, excitable tail. Feral ferrets, domesticated animals that have escaped human control, are still generally less aggressive than the larger, wild carnivores with which they have to compete, so their largest populations in Britain are found on islands. ${ }^{14}$

The idea of employing ferrets to kill rabbits was not a new one. The Greek author Strabo $(64 / 63 \mathrm{BC}-24 \mathrm{AD})$ describes how ferrets were specially bred for that purpose, and muzzled before being sent into rabbit burrows. ${ }^{15}$ The rabbits were driven out into the open, where they were caught by men stationed at the holes with clubs or nets. When the idea of rabbiting with ferrets became known during the middle ages, the practice became widespread in Europe. Rabbits and ferrets both arrived in England, possibly together, sometime between the eleventh and fourteenth centuries.

12 Oamaru Mail, 30 June 1887, 2.

13 J. Marchington, Pugs and Drummers: Ferrets and Rabbits in Britain (London: Faber and Faber, 1978).

14 T. W. Bodey, S. Bearhop, and R. A. McDonald, 'The diet of an invasive nonnative predator, the feral ferret Mustela furo, and implications for the conservation of ground-nesting birds', European Journal of Wildlife Research 57, no. 1 (2011): 107-17, doi.org/10.1007/s10344-010-0404-y.

15 A. P. D. Thomson, 'A history of the ferret', Journal of the History of Medicine and Allied Sciences 6 (1951): 471-80, doi.org/10.1093/jhmas/VI.Autumn.471. 
The introduction of invertebrate natural enemies is a standard technique for the management of insect pests, and can sometimes be spectacularly successful. ${ }^{16}$ But attempts to employ vertebrate predators to manage vertebrate pests seldom work so well, or at all, except under special conditions, and most turn out to have disastrous side effects. The story of mustelids in New Zealand is not only an interesting illustration of this generalisation, but also illustrates the interplay of social and biological factors in colonisation.

The aim of this paper is to describe the historical and social context of this unprecedented programme, to the extent that the original records still survive or can be deduced. I have presented the arguments proposed by supporters from both sides during the debates of the time.

\section{Methods}

Primary sources on the organisation of importations are preserved in New Zealand archives and research libraries. They comprise the documentary equivalent of an archaeological dig, in which careful extraction and interpretation can offer an incomplete but useful picture of the events and decisions of the time. The following account is based on extensive searches of these records.

Official reports of the New Zealand Parliamentary debates, and the Appendices to the Journals of the House of Representatives, are the most reliable and accessible sources, mostly already digitised. Handwritten letters, farm diaries and unpublished analyses are freely accessible but mostly not digitised, so are available only to readers on site. The main repositories are Archives New Zealand, Statistics New Zealand, and the Alexander Turnbull Library (all in Wellington); the Hocken Library (Dunedin); the Auckland Institute and Museum; the city libraries of Auckland and Dunedin; and the Maritime Museums of Auckland, Lyttelton, Port Chalmers, and Bluff. I have personally searched all of these except the Lyttelton Maritime Museum, which was closed in 2011 due to earthquake damage. I also commissioned professional archivists to search smaller New Zealand museums on my behalf. In England, I searched the National Archives at Kew, the Caird Library of the National Maritime Museum, the Bodleian Library, Oxford, and the Cambridge University Library.

By the mid-nineteenth century, there were dozens of provincial newspapers in New Zealand, each a rich source of information about local events and people, often reprinting significant items from correspondents and news publications overseas. ${ }^{17}$

16 J. R. Beddington, C. A. Free, and J. H. Lawton, 'Characteristics of successful natural enemies in models of biological control of insect pests', Nature 273 (1978): 513-19, doi.org/10.1038/273513a0.

17 E. Pawson and N. C. Quigley, 'The circulation of information and frontier development: Canterbury 1850-1890’, New Zealand Geographer 38 (1982): 65-76, doi.org/10.1111/j.1745-7939.1982.tb00995.x. 
Online newspaper databases offer easily accessible and valuable accounts of shipping movements, and reports of meetings showing how people reacted to the first ferret arrivals. ${ }^{18}$

Financial records are cited in the currency used in New Zealand in the nineteenth century, the British pound sterling (E), divided into 20 shillings (s), each of 12 pence (d). The Reserve Bank of New Zealand provides an online calculator by which sterling amounts back to 1862 can be converted into contemporary New Zealand dollars. ${ }^{19}$

\section{Results}

\section{Rabbits in New Zealand}

The European rabbit is a remarkably successful colonising species. ${ }^{20}$ Live rabbits are easily carried in small hutches on ships, and in the days before refrigeration they were a vital source of fresh meat for sailors on long voyages. Rabbits were distributed on islands around the world to provide food for castaways, and from the earliest days of the European diaspora, they accompanied pioneer farmers travelling to colonise new territories overseas. ${ }^{21}$

The first rabbits to arrive in New Zealand were probably brought by whalers to the south coast of the South Island. They were a normal article of trade at shore stations, so were shipped from Sydney during the two decades of the 1820s-1830s along with other supplies. ${ }^{22}$ There were reports of sightings of rabbits in southern New Zealand in the 1840 s and 1850s, although only in small numbers. ${ }^{23}$ As colonisation proceeded, rabbits were transported and liberated by settlers in several other parts of New Zealand, for sport as well as for meat. ${ }^{24}$

One story, about the introduction of rabbits to Southland in 1863, describes the occasion when four rabbits, brought to Bluff on the immigrant ship Helenslea from Scotland, were liberated in the sandhills near Invercargill:

18 Papers Past, National Library of New Zealand: paperspast.natlib.govt.nz; the British Newspaper Archive: britishnewspaperarchive.co.uk.

19 rbnz.govt.nz/monetary-policy/inflation-calculator.

20 H. V. Thompson and C. M. King, eds., The European Rabbit: The History and Biology of a Successful Colonizer (Oxford: Oxford University Press, 1994).

21 T. R. Dunlap, Nature and the English diaspora: Environment and history in the United States, Canada, Australia and New Zealand (Cambridge: Cambridge University Press, 1999).

22 Gibb and Williams, 'The rabbit in New Zealand', 158-204.

23 F. G. Hall-Jones, Historical Southland (Invercargill: H. \& J. Smith for Southland Historical Committee, 1945).

24 G. A. Hamilton, History of Northern Southland (Invercargill: Southland Times, 1952). 
There was a liberation ceremony with speeches and toasts drunk in champagne. But ... an old Highlander named Mitchell ... stood on a sandhill and cursed the rabbits in Gaelic, saying they would ruin the country. No one paid much attention at the time ... but many of those present must have lived to see the day [when Mitchell was proved right] $\ldots$ and remember his words..$^{25}$

The rabbits that arrived in the Helenslea were not the first brought to Southland, but by the 1870s, they were widely believed to have been the origin of what became an unstoppable horde of rabbits moving northwards into the hitherto highly profitable sheep runs of inland Southland and Otago. In the northern South Island, silvergrey rabbits were released in 1858 and in 1862, and they too reached pest levels in the early to mid-1870s. The historical geographer A. H. Clark cites Sir Alister McIntosh's 1940 history of Marlborough as estimating that more than a million acres $(404,685 \mathrm{ha})$ of sheep pasture in that province were damaged by rabbits in less than 15 years. ${ }^{26}$

According to the first official survey of what was called, with remarkable understatement, 'The Rabbit Nuisance', wild rabbits first appeared on the finely grassed and valuable sheep country among the sandhills between Invercargill and Riverton in about $1864 .^{27}$ Concentrated grazing by rabbits turned what had been a rolling sward into barren, shifting sandhills. From there, rabbits spread inland along the rivers, assisted by farmers, runholders and gold-diggers, who trapped and carried with them a few rabbits to supplement their sometimes meagre diets. ${ }^{28}$

By 1875, reports from Crown lessees (who held large blocks of leasehold grazing land for sheep runs) describing rapidly increasing pasture damage over the previous two years in Southland began to alarm the Provincial Council. One man quoted by the Otago Witness said that, from his own experience, 'the plague of rabbits has become so formidable, that it is now a struggle for existence between "fur v. wool"'. ${ }^{29}$

\section{Official inquiries}

In response to the concerns of Crown lessees in Southland, the Provincial Council instituted a commission of inquiry to investigate the extent of the 'rabbit nuisance' in the district, and to consider means of dealing with it. The commission appointed to investigate these reports doubted that such a sudden increase in rabbits could have been possible in the short time frame reported, and suspected that the case might be somewhat exaggerated.

25 Ibid., 34

26 A. H. Clark, The invasion of New Zealand by people, plants and animals: The South Island (New Brunswick, NJ: Rutgers University Press, 1949), citing A. D. McIntosh, ed., Marlborough: A Provincial History (Blenheim: Marlborough Provincial History Committee, 1940).

27 Richardson and Pearson, 'The Rabbit Nuisance in Southland'.

28 Hamilton, History of Northern Southland, 35.

29 Otago Witness, 9 December 1876, 21. 
Members of the provincial commission travelled widely around the affected districts, interviewing witnesses and consulting both those affected by it locally and the relevant authorities in New South Wales and Tasmania. They confirmed that the rabbits had indeed spread to the whole of Southland 'within the short period of two years'. They compiled figures documenting the reduction of the Southland wool clip by $700-800$ bales compared with the previous year, and losses of lambs averaging up to 20 per cent across the province per season, both attributed to malnutrition of ewes following rabbit damage to pastures. The commission listed the difficulties of exterminating rabbits caused by their extraordinary fecundity and the absence of natural enemies. They supported suggestions that importing a certain class of 'natural enemies' of the rabbit-but not such as would injure lambs-would relieve the country of a serious economic threat to pastoral agriculture. Their report of May 1876 called for a remedy that should be 'immediate, compulsory and universal', and urged the colonial secretary in Wellington to deem the matter of sufficient public importance to make it the subject of legislation by the General Assembly. ${ }^{30}$ A few months later, the Rabbit Nuisance Committee of the New Zealand House of Representatives recommended that a bill should be introduced to parliament without delay. ${ }^{31}$

Many businesses were about to be challenged by rabbits, but, faced with a completely unprecedented problem, they had no way to predict the size of the threat to their profits. For example, the National Mortgage and Agency Company of New Zealand Ltd (NMA) in Dunedin was a leading stock and station company, supplying livestock, seeds and equipment to pastoral runholders, and handling the sales of the wool and tallow they produced. They were among the first commercial entities at risk, but their directors saw no reason to be alarmed. In 1875 NMA's founder J. M. Ritchie wrote: 'I hear that Johnson has been spending upwards of $£ 15$ a week to try to keep down the rabbits. He is using men and dogs. Far better to get some ferrets.' Thirteen years later, in 1888, a member of the board, W. S. Davidson, speaking at a meeting of NMA shareholders in London, said: 'I have not the slightest doubt that we shall very easily keep the rabbits down in New Zealand. It only requires an increase in the numerous stoats and weasels which have been sent out to keep the pests in check. In a few years we shall be little troubled by rabbits.' The author of the centenary history of the company commented:

30 Richardson and Pearson, 'The Rabbit Nuisance in Southland'. The colonial secretary was the minister responsible for internal affairs, and was unconnected with the office of the Secretary of State for the Colonies in London.

31 Hodgkinson, 'Report of the Rabbit Nuisance Committee'. 
Here were two intelligent, prudent and successful men, quite sure that the rabbit problem was only a passing phase ... in the interval between the two statements [1875 to 1888] ... the Government had lost more than $£ 315,000$ [a year] in rentals from leasehold [pastoral] lands, and the annual national loss was being estimated at $£ 2,000,000.32$

Parry's figures differ from those given previously by Teschemaker, but the message is the same.

\section{Attempts to prohibit the importing of natural enemies}

Arguments over the wisdom of importing predators to attack rabbits soon developed into a serious political issue, focused on the strongly worded protests from ornithologists concerned about the risk to endemic fauna, including avian predators native to New Zealand. ${ }^{33}$ The same year, Sir George Grey attempted to prohibit the importation of foxes, polecats, stoats and weasels. ${ }^{34} \mathrm{He}$ proposed a Noxious Animals Introduction Prevention Bill that would have made such imports illegal. (Actually, foxes had already been prohibited in 1867, because of their known appetite for lambs, and the first mustelids had already been imported privately.)

The debate was stimulated at least as much by concerns about the potential damage to acclimatised game birds as by the potential threat to native birds. Grey's bill was passed by the House of Representatives, but the upper house, the Legislative Council, refused to consider it. Many members of the council were wealthy runholders at risk of losing serious amounts of money if the rabbit pest could not be controlled. Southern newspapers applauded the council's refusal to ban the imports, since they saw the natural enemies of the rabbit as more significant as defenders of the colony's commercial income from wool and crops than as threats to domestic poultry and game birds.

Despite the vigorous disputes, the imports remained legal. ${ }^{35}$ Just to make sure, when McMeckan, Blackwood \& Co., a firm of stock agents in Melbourne, received orders to export ferrets to Bluff in 1878 , they took the precaution of asking for permission from the colonial secretary in Wellington. They received the reply: 'There is no law against it, and ferrets are not mentioned in $\$ 2 \mathrm{~d}$ of Protection of Animals Act 1873.'36

32 G. Parry, N.M.A. The Story of the First 100 Years: The National Mortgage and Agency Company of New Zealand Ltd 1864-1964 (Dunedin: The National Mortgage and Agency Company of New Zealand Ltd., 1964), 122.

33 Otago Witness, 9 December 1876.

34 P. K. Wells, "'An enemy of the rabbit": the social context of acclimatisation of an immigrant killer', Environment and History 12 (2006): 297-324, doi.org/10.3197/096734006778226373.

35 House of Representatives, 'Amendment to Protection of Animals Bill' [re bannning imports of mustelids], New Zealand Parliamentary Debates (Wellington: G. Didsbury, Government Printer, 1876), 273.

36 W. Bishop, Letter 13 July to Colonial Secretary asking permission to land 2 dozen ferrets, 1878. Archives New Zealand, Wellington, R24273700. 


\section{Early private importations of ferrets}

Not every ferret that reached New Zealand was brought in for rabbit control. A few ferrets found their way in even before rabbits became a nuisance-as demonstrated by an advertisement of 1852 offering three pairs for sale, and another in 1860 offering four ferrets at 35 shillings a pair. In 1867, the Bella Mary brought 10 ferrets from Hobart, 'which will be parted with on reasonable terms' ${ }^{37}$ Ferrets had long been useful for purposes other than release, such as for clearing buildings of rats, so private imports had been going on since the late 1860s. For example, the Canterbury Acclimatisation Society brought in five ferrets in 1867, plus another one in 1868, and kept them at its gardens in Christchurch. ${ }^{38}$

'Working ferrets' were trained to hunt rabbits alongside a man and a team of dogs (Figure 2). Ferrets were inserted into the burrows to flush the rabbits out into the jaws of the dogs, and afterwards retrieved. Good working ferrets were valuable property, and well cared for because they were part of their owners' toolkits. Farmers advertising for labourers favoured rabbiters with their own ferrets, and immigrants skilled in such work were much in demand. These ferrets were not intended for release, and any that got lost were not expected to be able to survive for long independently of human partners.

The area of ground that a ferreting team could cover was limited, and the need to control rabbits over vast areas of seldom-visited mountain country was very great. So it was the runholders in those districts who were the first to try importing private shipments of ferrets for release on their own land, and to persuade the government to do the same for Crown lands, and on a large scale. Inevitably, the emphasis shifted to importing ferrets in very large numbers, specifically to be liberated into the wild.

The chances of the released ferrets surviving long enough to establish a wild population varied with the habitat and climate of the distribution area, and with their own ability to adapt to an independent life. One objection to releasing captivebred ferrets was that, after generations of selection for the docile qualities preferred in tame domestic animals, they might be unable to make a living independently. That was certainly an issue at first, when young ferrets were turned out straight from a comfortable hutch into the unprotected wild. One of the ferrets' keenest supporters, Teschemaker, conceded that domestic ferrets were more delicate than the stoat or weasel, and did not survive the English winter if left unprotected. New Zealand was different, he added, because there was so much food available for them, and they could survive well here, especially if they were trained to hunt and kill before being turned out. ${ }^{39}$

37 Lyttelton Times, 7 August 1852; Daily Southern Cross, 27 January 1860; New Zealand Herald, 1 February 1867.

38 G. M. Thomson, The naturalisation of animals and plants in New Zealand (Cambridge: Cambridge University Press, 1922), 70, doi.org/10.5962/bhl.title.28093.

39 C. de V. Teschemaker, Letter to Major Atkinson [NZ Premier] on obtaining information on stoats and weasels, 1883. Archives New Zealand, Wellington, R24413234. 


\section{Otago}

Soon after rabbits arrived in Otago in the mid-1860s, the economic viability of the backcountry sheep stations, including two of the largest, Earnscleugh and Galloway, began to decline rapidly. By June 1875, the local papers were reporting that the squatters (runholders) were planning to do something about the rabbits, starting with ordering supplies of ferrets for Earnscleugh and Galloway stations (Figure 1).

This first 'supply' of ferrets for Earnscleugh amounted to only five animals in 1875, but then in the 1880s the station staff started breeding their own ferrets for release. ${ }^{40}$ The ferrets did not save Earnscleugh; it was resumed by the Crown (that is, it was abandoned by the leaseholder) in 1895 , by which time it could carry only 12,000 sheep, half the number it had supported in 1879 .

Life at Benmore station, in the Waitaki Valley in northern Otago, is well recorded in a series of diaries and letters written by the station manager Thomas Middleton, and summarised by Robert Pinney. ${ }^{41}$ Ferrets were first taken there in 1875 , and by 1881 they were 'all over the run'. ${ }^{42}$ Middleton attributed his moderate early success in reducing the numbers of rabbits in part to the work of ferrets, but regretted that they were so vulnerable to the effects of the highly infectious and lethal disease canine distemper, and of eating the carcases of poisoned rabbits.

The unpublished ledgers of the Dunedin office of the New Zealand Loan \& Mercantile Agency Co. are being prepared for cataloguing by the Hocken Library. Among them, Peter Holland found several entries for consignments of mustelids to J. C. Buckland at Tumai, dating from $1882 .{ }^{43}$ These animals were presumably imported into Bluff (probably from Melbourne) and forwarded to the Dunedin office for distribution to client landholders.

40 R. Peden, Making Sheep Country: Mt Peel station and the transformation of the tussock lands (Auckland: Auckland University Press, 2011).

41 R. Pinney, Notebook M1: Extracts from Benmore Letter Books, 1877-1887. Hocken Collections, Otago University, MS-3178/013.

42 Pinney, Early Northern Otago Runs.

43 Waikouaiti, 27 November 1882: 'Ferrets from Invercargill E6-17-6'; 23 December 1882: 'Ferrets from Invercargill £24-10-0’; 9 April 1884 'Exp[ense]s re stoats, ferrets etc, 13s 0d’. Peter Holland, personal communication. 


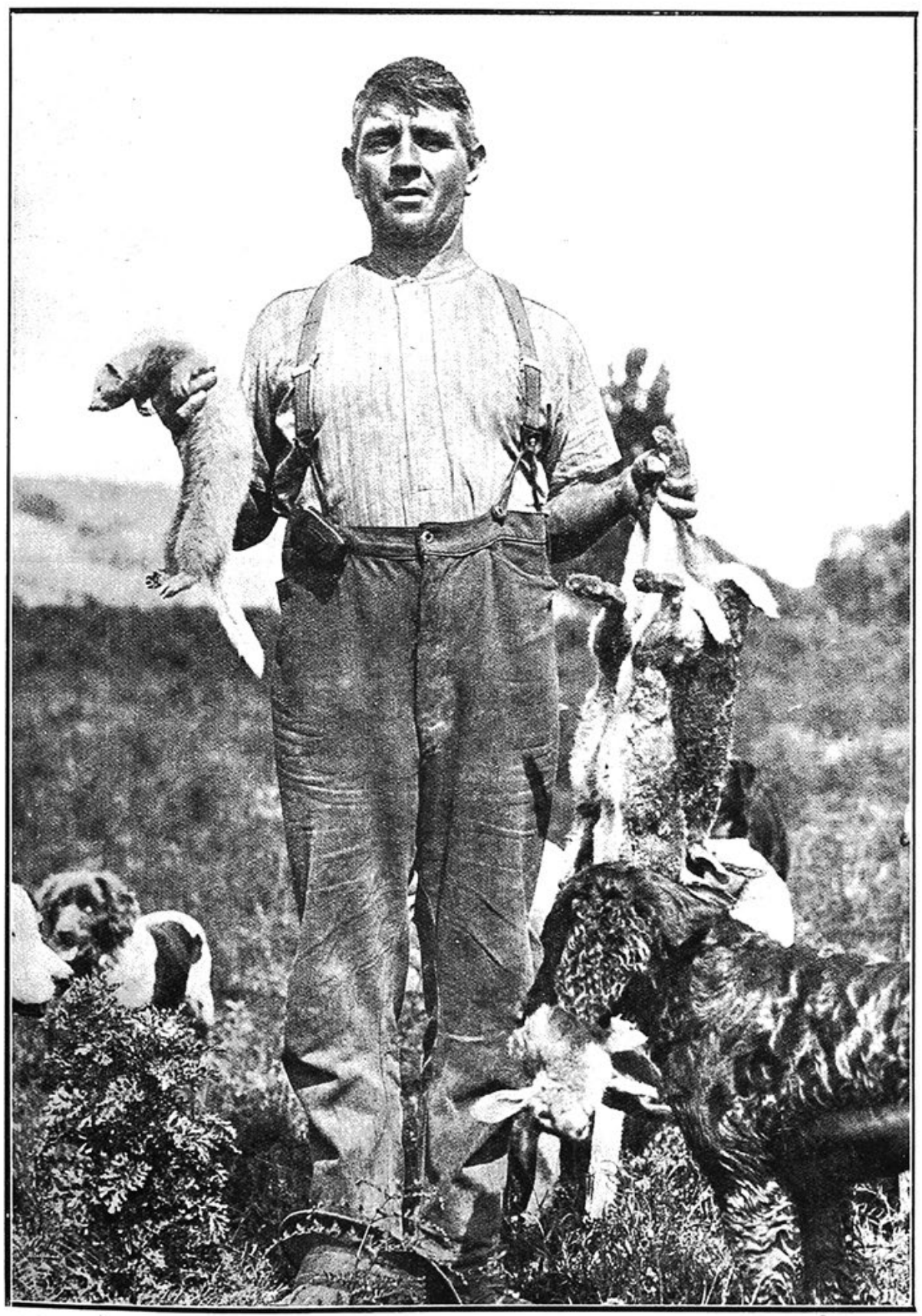

Figure 2: A rabbiter working with a cooperating team of dogs and ferrets. Source: Sir George Grey Special Collections, Auckland Libraries, AWNS-19241211-41-2. 


\section{Southland}

Cuthbert Cowan was a leading Southland runholder and a member of the House of Representatives. His property at Okaiterua on the Oreti River was one of the first to be invaded by rabbits, from 1872 onwards. Between March and July 1876, Cowan killed 26,000 rabbits on his own 11,750 acres (4,755 ha) alone, by the efforts of men with spades, dogs and one gun. ${ }^{44} \mathrm{He}$ organised a private shipment of ferrets from Britain, which arrived in late 1876:

One of the passengers by the Arawata on her last trip from Melbourne, was a young gentleman [Allen Bowler] ${ }^{45}$ who brought 36 ferrets in the St. Osyth from England to Melbourne and thence to this place, for rabbit killing purposes. He has proceeded to $\mathrm{Mr}$ C. Cowan's station. ${ }^{46}$

At a parliamentary enquiry in 1884, Cowan was asked if he had ever tried natural enemies as a remedy against rabbits. He replied that he had landed 16 ferrets and put them out on his own property. Now the country was 'overrun with ferrets', which were breeding in the wild and doing no harm to lambs. ${ }^{47}$

\section{Marlborough}

In 1878, Joseph Ward of Wairau and some of his neighbours ordered a consignment of ferrets to be dispatched from England in the sailing ship Rialto. On the voyage, distemper broke out among them, and when the ship arrived on 6 March 1878, only three ferrets had survived, so 'it was a rather expensive affair' ${ }^{48}$ Another lot of 600 ferrets was imported by George Bullen of Kaikoura, but every one of that consignment died. He started again with 700 , and got two ferrets out of the $1,300 .{ }^{49}$ The two shipments cost some $£ 800$, for virtually no result. A later and presumably better-managed shipment cost 10 s $81 / 2 \mathrm{~d}$ per ferret, in part because by then it was known that ferrets had to be kept well away from any dog with distemper. Besides disease, another likely reason for these failures was inappropriate feeding and housing on board ship. Gamekeepers with long experience of keeping ferrets described them as shivery creatures that need warm, dry hutches, ${ }^{50}$ and always thirsty, so they must be given plenty of water. ${ }^{51}$

44 Gibb and Williams, 'The rabbit in New Zealand', 162.

45 Immigration Register for 1876. Archives New Zealand, Wellington, R5013063 Im W2/2.

46 Southland Times, 15 November 1876, 2.

47 G. Randall Johnson, 'Report of the Joint Committee on Sheep and Rabbit Acts', AJHR I-5 (1884).

48 Anon., 'Report of the Rabbit Nuisance Committee' [1880-81], AJHR I-06 (1881).

49 Randall Johnson, 'Report of the Joint Committee on Sheep and Rabbit Acts'.

50 R. Jefferies, The Gamekeeper at Home (Oxford: Oxford University Press, 1978 [first published 1878]).

51 Marchington, Pugs and Drummers: Ferrets and Rabbits in Britain. 
Bullen also encouraged British ferreters to emigrate to New Zealand, bringing their working ferret and dog teams with them. These shipments were more successful, not least because these animals were accompanied by experienced ferret-keepers. For example, the ship Warwick left Plymouth on 30 November 1878, arriving at Lyttelton on 3 March 1879. The Nelson Evening Mail announced that the Warwick carried two rabbit-catchers accompanied by their ferrets and dogs, and engaged to work for 'a runholder at the Kaikouras'. They were to be paid between $4 \mathrm{~s} 6 \mathrm{~d}$ and $2 \mathrm{~s}$ $6 \mathrm{~d}$ per dozen rabbit skins, depending on the time of year. The Warwick's passenger list names all the men on board with their trades: two of them, David Cook and David Lang, both 23 and both from Fife, were listed as rabbit-catchers. ${ }^{52}$ Bullen is named in another report as the runholder engaging them.

Other Marlborough runholders tried a different tactic. Fell Brothers, agents for the Starborough station near Blenheim, offered to pay stewards and others working on the wool ships 12 shillings a head for all ferrets landed alive and in healthy condition. The adverts were repeated at least five times over the next two months. ${ }^{53}$ If any ferrets came in this way, they could only have been in small numbers.

\section{North Island}

Wild rabbits liberated in the southern Wairarapa near Carterton had greatly increased in numbers by $1870,{ }^{54}$ and by 1875 they had reached William Beetham's station Brancepeth, southwest of Masterton, about $15 \mathrm{~km}$ away. ${ }^{55}$ Further south, the Huangarua station near Martinborough was owned from 1869 to 1878 by the Hon. George Waterhouse, a Wellington politician and pastoralist. He had had rabbits on his property since about 1871 . Waterhouse was one of the speakers in the Legislative Council debate on whether to impose a ban on introduced predators in 1876. He must have been relieved at the decision that private imports were not to be prohibited, because during the debate he revealed that 'he had, within the last three or four months, turned loose a considerable number of ferrets'..$^{56}$

The result was apparently good. Runholders in Southland read, perhaps with a touch of envy, reports that the ferrets imported by Waterhouse, released on pastures thick with rabbits, had cleared them out completely by January 1877 , right down to the last one in the neighbourhood. Such unequivocal statements are now impossible to test, but seem to modern eyes incautious: absence of evidence (of rabbits surviving the arrival of ferrets in a locality) is not evidence of absence of rabbits, there or anywhere.

52 Nelson Evening Mail, 4 March 1879, 2; Ship's papers for Warwick Nov. 1878 - Mar. 1879. Archives New Zealand, Wellington, R $4085568 \mathrm{Im} 15 / 345$.

53 For example, Evening Post, 5 December 1881, 3.

54 Gibb and Williams, 'The rabbit in New Zealand', 162.

55 W. H. McLean, Rabbits Galore (Wellington: A. H. and A. W. Reed, 1966).

56 House of Representatives, 'Amendment to Protection of Animals Bill' [re bannning imports of mustelids], New Zealand Parliamentary Debates (1876), 273. 


\section{The Rabbit Nuisance Act 1881}

By 1880 the government could no longer ignore the outcry from formerly wealthy runholders facing ruin from rabbit damage. Their influence had been the main reason for the failure of Grey's 1876 attempt to prohibit the import of the natural enemy of the rabbits. Now, as rabbits steadily advanced through Otago from Southland, they wanted more decisive action. Native predators (harrier hawks: Circus approximans; and the predatory flightless weka: Gallirallus australis hectori) killed many rabbits at first, but soon it became clear that leaving the task to them alone was not going to be enough. Thomas Middleton, manager of the Hon. Robert Campbell's Benmore station in the Waitaki River Valley, northern Otago (Figure 1), wrote to his employer in May 1881 that rabbits were becoming a serious concern on the estate. ${ }^{57}$ He begged Campbell to do something urgently:

Now, if ever, is the time to prevent them becoming a nuisance ... I can't help dreading the fate of Southland for the Waitaki unless we stir ourselves and combat the vermin before it is in their power to do us harm. ${ }^{58}$

Alas, serious harm was already being done. By 1881 the rental income to the government from the half-million acres (202,342 ha) of runs severely affected by rabbits had dropped from $£ 2,288$ a year to $£ 619$, and the financial cost to the whole colony in lost exports had escalated to at least $£ 500,000$ a year. On one of Campbell's runs, Galloway (68,000 ha), rabbit control in 1880 cost him $£ 3,000$ (equivalent to $\$ 486,193$ now) for a return of $£ 1,500 ; 26,000$ ha of the run was incapable of feeding sheep in winter. Burwood, another of Campbell's runs, used to carry 80,000 sheep, but could by then support only 24,000. Campbell gave up on this and six more of his runs in 1881; four were relet at a lower rent, and three were simply abandoned. The national flock fell from 13 million sheep in 1878 to 11.5 million in 1879.59

The Rabbit Nuisance Committee reported detailed statements from 15 witnesses. They specifically wanted to see all landholders required to bear their proportionate share of the cost of destroying rabbits, and provision made for protecting the natural enemies of the rabbit already in the colony.

Among the witnesses was Bullen. He presented a succinct argument in favour of relying on ferrets to solve the rabbit problem:

I am glad to say the ferrets have done, and are still doing, a great work for us in checking the rabbits; and I do believe the ferrets will be the salvation of the country ... My firm belief is, the rabbit-catchers do more harm than good: they kill everything

57 Pinney, Early Northern Otago Runs.

58 Pinney, Notebook M1: Extracts from Benmore Letter Books, 1877-1887. Hocken Collections, Otago

University, MS-3178/013.

59 Anon., 'Report of the Rabbit Nuisance Committee' [1880-81]. 
that kills a rabbit ... We turned out ferrets about eight years ago, and have been turning out ... about two hundred a year, which we shall continue as long as we see any rabbits around ... This country ... is considerably over 100,000 acres, and I believe there are many hundreds of ferrets on it; we leave it entirely to them to do the work, keeping one man to breed and act as keeper over the ferrets. ${ }^{60}$

The experience of Bullen, among others, convinced the colonial government to take action. The existing Rabbit Nuisance Act 1876 had provided only for a system of district rabbit trustees with powers to raise funds from landowners to help pay for the work of dealing with rabbits (excluding unoccupied Crown and Native lands). This did not work well, largely because it could not prevent landholders who disagreed with it from simply walking away. Some more vigorous action was needed.

In November 1881 a new and energetic Chief Inspector, Benjamin P. Bayly, was appointed. ${ }^{61}$ Bayly was a strong supporter of the idea of importing mustelids to control rabbits, so he immediately set to work on organising official purchases of ferrets for release on Crown lands. He also helped to draft new legislation ${ }^{62}$ that provided for resident rabbit inspectors in every district, armed with the power to hold individual landholders responsible for controlling rabbits on their own land. Defaulters could be fined up to $£ 20$, which seemed the crowning insult to many runholders already facing unavoidable financial losses due to rabbits. The new Act also gave legal protection for all natural enemies of the rabbit already present (ferrets, cats, stoats, weasels and mongooses, but not the weka, because it was traditional food for Māori). ${ }^{63}$ The penalty for killing any one of these was up to $£ 10$, and there were no exemptions, even to protect poultry or carefully nurtured game birds. With minor alterations, this Act remained in force for many years.

As the advancing horde of rabbits moved northwards from Southland into Otago, the government planned to establish resident populations of natural enemies to stand in their way. The need to do this was considered especially urgent where labourintensive methods of rabbit control were impossible, such as on the unoccupied Crown lands of the remote backcountry. So thousands of ferrets were released on the mountains dividing the headwaters of the main eastward-flowing rivers, and on the western sides of the lakes. This policy was not understood at the time, or later-especially by those concerned about the protection of native birds. For example, Edward Melland held two pastoral leases in far western Otago, Eglinton 394 and Cheviot 396 (Figure 1). He was also a scientist, and was twice president of

60 Ibid., 17.

61 'Notices' [Appointment of B. P. Bayly], New Zealand Gazette, 18 November 1881, 2.

62 Rabbit Nuisance Act (1881): www.nzlii.org/nz/legis/hist_act/rna188145v1881n6222.

63 C. M. King, 'Contemporary observations of predation on the buff weka (Gallirallus australis hectori) by ferrets in the South Island during the nineteenth century', Notornis 64 (2017): 52-5. 
the Otago Branch of the Royal Society of New Zealand. In 1889, Melland criticised the government's 'incredible folly' in turning out ferrets on the west shore of Lake Manapouri, where kakapo, then still common, are now extinct. ${ }^{64}$

\section{Reactions to the new Act}

Rearguard protests continued in the House of Representatives. In July 1882 the colonial secretary was asked, in view of the conflicting opinions expressed as to the introduction of ferrets and weasels to overcome the rabbit nuisance, would government cause the matter to be more fully considered? The minister replied that the government had not sufficient reason to doubt the expediency of importing ferrets as a means of overcoming the rabbit nuisance. ${ }^{65}$ The government continued, not only commissioning many imports itself, but also subsidising private enterprises doing the same.

Settlers' meetings debated the new Rabbit Act exhaustively and often angrily. For example, the Marlborough Express reported in great detail the proceedings of two successive meetings in Blenheim in October and November 1881. In the face of a growing fear that, if the advance of the rabbits was not stopped, they might as well give up sheep farming altogether, every possible method of meeting the Act's requirements had its passionate advocates. For some, poisoning and fencing were the only solutions; for others, organised breeding and distribution of ferrets. Some relied on trapping to remove the rabbit pest, while others pointed out that rabbiters could not be expected to remove the source of their employment, and their traps also killed many natural enemies of the rabbit.

Plagued by repeated and increasingly hostile correspondence, the government was forced to justify its policy. Bayly dismissed all objections to government releases of mustelids in the backcountry as coming from those who had

evidently never been south or seen the damage caused by the rabbit pest ... [and are unaware that] private individuals have and are introducing the natural enemy and turning these animals out within the settled districts ... I am as strongly as ever a believer in the introduction of the natural enemy ... to save the large tracts of pastoral country in Canterbury that are threatened with an influx of rabbits from the boundary of the Otago country ... [where it is] impossible to deal with [rabbits] in the ordinary manner, it is here especially that the natural enemy is required. ${ }^{66}$

64 E. Melland, 'Notes on a paper entitled “The takahe in western Otago" by Mr James Park, F.G.S', Transactions \& Proceedings of the New Zealand Institute 22 (1889): 295-300.

65 New Zealand Parliamentary Debates, 12 July 1882, 242-3.

66 Correspondence protesting introduction of stoats and weasels, 1886. Archives New Zealand, Wellington, R24456501. 
Not everyone was convinced that ferrets would be able to control rabbits at all, let alone as effectively as claimed. Richard Henry (1845-1929) was an ardent conservationist, later famous for attempting to protect New Zealand's endemic flightless birds from mustelids by translocating them to Resolution Island. ${ }^{67}$ He once watched a ferret failing to catch a rabbit put in an enclosure with it. Henry recommended that anyone thinking of purchasing ferrets for release on a property should first undertake a few simple experiments, which would enable the experimenter to estimate whether there was any point in Bayly's official policy of buying up young ferrets at $8 \mathrm{~s}$ or $10 \mathrm{~s}$ each, and turning them straight out of cages by the thousands. Henry's advice was ignored. ${ }^{68}$

Opponents continued to claim that ferrets would prove to be a cure worse than the disease, but any such prediction could be countered by reassurances from supporters of the programme, such as C. J. Tully. He told the Joint Committee on Sheep and Rabbits in 1884 that ferrets were so easy to catch, there was no need to fear that ferrets would become too numerous. ${ }^{69}$

\section{Official ferret importations, 1882-86}

By the time of Bayly's first report to the House of Representatives in 1882, he was able to say that several shipments of ferrets had been procured from Melbourne, and small lots were expected regularly by sailing vessels from England. ${ }^{70}$ The inwards letter books kept at the colonial secretary's office in Wellington record a long series of letters from London in that year concerning shipments of ferrets. Most of these letters are now lost, so it is now difficult to tell where the animals came from, but one letter of 5 October 1882 from the agent-general in London mentions a shipment sent in September by a dealer 'from the Clyde'. ${ }^{71}$ The public accounts for 1881-82 list expenditures of $£ 12210$ s for purchasing ferrets and $£ 2815$ s for their hutches. ${ }^{72}$

The annual volumes of Statistics of the Colony of New Zealand include comprehensive listings of imports and exports by item and origin. Under 'Animals, living', a total of 1,972 animals listed as 'Livestock: other kinds' are recorded as having been imported from Australia and the UK between 1870 and 1880 inclusive, that is, before the arrival of the first stoats and weasels. Another 590 animals were recorded

67 S. Hill and J. Hill, Richard Henry of Resolution Island (Dunedin: John McIndoe, 1987).

68 R. Henry, The New Zealand Rabbit and its prey (Christchurch: Lyttelton Times, 1887).

69 'Report of the Joint Committee on Sheep and Rabbit Acts', AJHR I-5 (1884): 137.

70 B. P. Bayly, 'Livestock and Rabbits (Report as to Rabbits)', AJHR H-21 (1882).

71 Agent-General, 'Forwarding information re Marten cat', 1882. Archives New Zealand, Wellington, R24375311.

72 'Public Accounts of the Government of New Zealand', AJHR B-01 (1881-82). 
as having been imported in the five years 1882-86; though listed as 'Ferrets and weasels', until 1885 they were mostly ferrets from Australia, where there were no stoats or weasels. ${ }^{73}$

Bayly's early enthusiasm was quickly tempered by unpleasant surprises. A serious problem with transporting ferrets around the world was that, as Bullen had already discovered, these shipments were often disastrous failures. A letter from the colonial secretary in Wellington to the agent-general in London, dated 9 September 1882, included a memorandum listing the very high mortality rates of shipments of ferrets from Britain. ${ }^{74}$ The losses in transit were caused partly by inexpert handling, and partly by the great susceptibility of ferrets to canine distemper, which between them killed at least three entire shipments, each of up to 600 ferrets.

Among the suppliers of live animals for export from England was a well-known animal dealer, William Cross of Liverpool. He sent 120 ferrets, accompanied by 750 pigeons, 10 sacks of biscuits and 375 tins of Nestle's milk as food for the ferrets on the voyage, to 'a large wool farmer' in New Zealand. Cross quoted his client as believing he was facing ruin unless he could prevent the rabbits from eating up the pasture on which his sheep ought to be feeding, so he told Cross to send the order regardless of the expense. ${ }^{75}$

Curiously enough, at about the same time Mr Cross was also commissioned to send 2,000 live rabbits to British Columbia. News editors in New Zealand were quick to point out the irony of $\mathrm{Mr}$ Cross supplying rabbits to be introduced into one country, and carnivores to help the extermination of introduced rabbits in another country. Why, they asked in England (and in New Zealand), have not the western Canadians learned from what rabbits have done to New Zealand and Australia? ${ }^{76}$

Bayly's 1883 report to the Rabbit Nuisance Committee listed the losses recorded from 25 shipments of ferrets landed between March 1882 and 30 June 1883:

Of a total of 1217 ferrets shipped from England, 178 were landed alive, at a cost of $£ 953$, plus 241 shipped from Melbourne between March and April 1882, of which 198 landed alive, at a cost of $£ 224$ - to which must be added 122 for natural increase, less 157 that died from distemper. In total, 376 ferrets were landed alive by Government. ${ }^{77}$

73 C. M. King, 'Pandora's box down-under: Origins and numbers of mustelids transported to New Zealand for biological control of rabbits', Biological Invasions (2017): doi.org/10.1007/s10530-017-1392-6.

74 Colonial Secretary, Letter 9 September to Agent General [Cover letter re Bayly report ferret deaths], Outwards Letterbook-Agent-General, 1882. Archives New Zealand, Wellington, R20557923.

75 Evening Post, 17 December 1887, 1.

76 The Standard, London, reprinted in Hawke's Bay Herald, 29 December 1887, 3.

77 B. P. Bayly, 'Annual Report on the Rabbit Nuisance' [1882-83], AJHR H-18 (1883). 
The final straw was the voyage of the sailing barque Lastingham, commissioned in London by the agent-general in April 1883 to carry a shipment of ferrets to New Zealand under the care of Francis Court. ${ }^{78}$ All the ferrets died on the way. The colonial secretary directed the agent-general to dispatch all future shipments in steamships, and to ensure that all consignments be accompanied by someone 'with knowledge of the animal'. ${ }^{79}$

On top of losses in transit, competition with private interests was making it increasingly difficult for the government to meet its strategy of obtaining large cohorts of ferrets for liberation on Crown lands. Bayly found that the private demand for ferrets meant that the government had been able to buy only two or three lots during the year 1883-84. Teschemaker complained: 'I lately sent to Dunedin for 20 pairs of ferrets ... [the dealer] could only supply me with six pairs and I was told he could have sold them ten times over.' ${ }^{\text {'80 }}$

By the end of 1883 , it became clear that the policy of importing ferrets was never going to be economic. Local breeding was fast becoming a feasible and more attractive alternative, so Bayly shifted to a different strategy, the purchasing of ferrets bred in the colony for sale to the government at a fixed price per head. Official importations of ferrets ended in $1884,{ }^{81}$ although private shipments continued until at least 1886.

\section{Ferret-breeding programmes, 1882-c.1920s}

The earliest ferret-breeding programme was established in the mid-1870s in Christchurch by the Canterbury Acclimatisation Society. The curator of its gardens, A. M. Johnson, kept ferrets there for Mr Morton, a member of the society, on whose behalf he sold some of them; two were still there in $1874 .{ }^{82} \mathrm{~A}$ larger breeding programme began there in 1882, when 20 ferrets were brought in for the government, which was to pay for their food and upkeep, at a daily cost of $31 / 4 \mathrm{~d}$ per ferret. A hutch was built for them costing $£ 46$ 12s. By December 1882 their numbers had increased to 60 , and their hutch was enlarged. ${ }^{83}$

In 1882, the government established three new depots for breeding ferrets, at Waimata and Masterton in the North Island, and near Christchurch in the South Island, and many other establishments followed, as listed by local rabbit inspectors contributing

78 Agent-General, Letter No. 82 of 4 April to Colonial Secretary: Shipment of ferrets per 'Lastingham' in charge of F. Court, Inwards Letter Book (1883): 316. Archives New Zealand, Wellington.

79 Colonial Secretary, Letter 1 August to Agent General [Ferrets to be carried on steamships], Outwards Letterbook-Agent-General (1883). Archives New Zealand, Wellington, R20557923.

80 Teschemaker, Letter to Major Atkinson on obtaining information on stoats and weasels (1883).

81 B. P. Bayly, 'Annual Report on the Rabbit Nuisance' [1883-84], AJHR II H-02 (1884).

82 R. C. Lamb, Birds, beasts and fishes: The first hundred years of the North Canterbury Acclimatisation Society (Christchurch: North Canterbury Acclimatisation Society, 1964), 19.

83 Lamb, Birds, beasts and fishes, 21. 
to Bayly's annual reports. Most of these animals were bred for distribution and release on Crown lands, but private owners, notably Bullen in Marlborough, ran their own programmes, turning out up to an additional 500 ferrets in one season. The total numbers of ferrets released by all parties reached extraordinary levels by the mid-1880s.

The Joint Committee of the Canterbury Chamber of Commerce and the Canterbury Agricultural and Pastoral Association feared rabbits arriving in Canterbury in their myriads. They were confident that judicious placement of natural enemies through the backcountry would prevent such an invasion, and in December 1887 the Christchurch Press summarised a public meeting held to consider their report. The committee urged the government to accelerate the production processes by offering a bonus for ferret breeding.

Among the large stations establishing their own ferret-breeding facilities was Benmore, which had a breeding stock of 112 doe and 23 buck ferrets at the homestead, and also bought ferrets bred at Quail Burn and Mount Royal, also in Otago. In April 1888, 689 ferrets were turned out on the station, most of them locally bred. Still, rabbit numbers remained astronomical: 40,000 were killed on Benmore in February-March 1889 alone. $^{84}$

While the demand lasted and official encouragement continued, the ferret-breeding business paid some enterprising operators very well. In September 1888, George Steel of the New Zealand Country Journal visited a private ferret stud at Wairuna Hills (inland from Balclutha) run by Messrs Allen and Riggs. They had a contract to supply the colonial government with 10,000 ferrets a year for three years, at $7 \mathrm{~s}$ $6 \mathrm{~d}$ a head. The breeding stock numbered 200 full-grown ferrets, of which 40 were males. They ate 30 rabbits a day, plus the milk of three cows, and every detail of their diet, housing, mating, and nursing of offspring was carefully managed to keep them healthy. ${ }^{85}$

Ferret breeding was a long-term and risky operation, so the government had to offer private breeders a guaranteed purchase price for their ferrets in order to get them to invest in it. Such a system created an unforeseen problem: an attractive opportunity for dishonest profiteering. In districts where large numbers of ferrets had already been turned out, a high price offered for live ferrets gave rabbiters an incentive to poach wild ferrets and offer them for sale. In order to ensure that sheep inspectors were not buying back their own previously released ferrets, the government had to change the rules to authorise purchases only from known breeders. ${ }^{86}$

84 Pinney, Early Northern Otago Runs; R. Pinney, Notebook L: Extracts from Benmore Diaries, 1866-88. Hocken Collections, Otago University, MS-3178/012.

85 George Steel in the New Zealand Country Journal, quoted in Otago Witness, 28 September 1888, 7.

86 A. Macdonald, [Authority to buy ferrets], 1886. Archives New Zealand, Wellington, R24456331. 
In turn, local sheep inspectors had to check if more ferrets were needed. For example, in February 1886, W. A. Smith wrote to E. Clifton, the sheep inspector at Kaikoura, offering ferrets for sale at 10s each. Bayly confirmed that ferrets were needed for turning out on Crown lands, so the colonial secretary authorised Clifton to buy as many young, healthy and properly seasoned ferrets as were offered, at not more than 10 s each, or less if possible. ${ }^{87}$

In the southern South Island, the local rabbit inspectors believed that ferrets had proved their worth, because in some areas the rabbits were rapidly disappearing, and in their place ferrets could be found in considerable numbers. Bayly's 1887 annual report on the rabbit nuisance lists a total of 1,922 ferret releases during the year (800 in Southland alone), and others went unrecorded. The inspector for Gore, Angus Macdonald, reported that ferret breeding had become an industry in his district, and agreed that breeders should be licensed to reduce the temptation to traffic illegally in government stock. ${ }^{88}$

The following year's annual report claimed with pride that ferret breeding was now being carried out on a large scale; 3,600 ferrets had been bred and 2,755 released in Otago, 367 in Canterbury, 480 in Marlborough, in addition to more than 4,000 by private owners. A separate report lists contracts on foot for a total of 21,760 ferrets to be supplied to the government's stock department from 1 January 1887 to 8 June 1888. All the consignees were rabbit inspectors in the South Island, although a footnote adds that fewer than half of the contracts were expected to be met. ${ }^{89}$

\section{The end of the official strategy, 1889-91}

Eventually there had to be an end to this programme, and it came during 1888-89. In 1889, Bayly was demoted, and the government withdrew all support for his policies. The independent Joint Committee on Livestock and Rabbits produced its annual report in September 1889, protesting against the sudden change, but to no effect. The rabbit inspector for Otago, Alfred Douglas, had reported that 2,230 ferrets had been produced for purchase by the government and turned out on the high country in 1890 , but when breeders found that the government had stopped all contracts, they simply released 5,000 of their stock. ${ }^{90}$

From then on, private enterprise was left to meet the demand for mustelids by direct negotiation with purchasers. A private shipment of 185 'polecats' and ferrets intended for the South Island and dispatched in the Aorangi from London on 9 January 1891 did nothing to help the shortage, since only two arrived alive; the

87 W. A. Smith, [Ferrets for sale], 1886. Archives New Zealand, Wellington, R24455151.

88 B. P. Bayly, 'Annual Report on the Rabbit Nuisance' [1886-87], AJHR H-18 (1887).

89 Stock Department, 'The supply of ferrets (contracts made by Stock Department)', AJHR H-31 (1888).

90 Anon., 'Annual Report on the Rabbit Nuisance' [1889-90], AJHR H-9 (1890). 
rest died on the voyage. But private breeders gradually recovered their confidence in the ferret-breeding business to supply the newly established rabbit boards, and the local ferret production industry continued long after all shipments of mustelids ended in $1892 .{ }^{91}$

For example, the North Wairarapa Board turned loose about 1,000 ferrets in 1892-93, and in Marlborough, hundreds of ferrets were liberated in that spring and summer, with many more following. ${ }^{92}$ In February 1899, the sheep inspector at Gore, E. Field, wrote to Ritchie that he could get local breeders to commit to producing any number of ferrets up to 1,000 at $5 \mathrm{~s}$ each, provided the government guaranteed it would purchase them in September. Ritchie recommended that Field order 1,000-1,500 for liberation on Crown lands, where Ritchie considered that the natural enemy were doing excellent work in the high country. ${ }^{93}$

In all, the 50-year history of attempts to use ferrets to control rabbits in the South Island involved tens of thousands of animals. Clark cites an unpublished estimate by the historian R. M. Burdon that overall 'upward of 75,000' ferrets were bred and released..$^{94}$ The written records are full of astonishing figures that are too fragmentary and scattered, and too often overlapping, to add up to an actual count, but they are consistent with Burdon's figure taken over the long term. With hindsight, we may now ask to what extent this unprecedented programme achieved its aim.

\section{Effects of mustelids on rabbit numbers}

First, it is necessary to draw a clear distinction between two quite different predatorprey relationships. Island species that evolved in habitats free of any four-footed mammalian predators, which include all of New Zealand's most strongly endemic birds, typically have very low breeding and mortality rates. Suddenly increased subtraction imposed by a new invader can easily beat multiplication of the residents, and reproduction is overwhelmed by unmanageable losses, as is illustrated by the long list of New Zealand's extinct birds. ${ }^{95}$ Lethal control of invasive predators to protect a threatened island fauna is effective and fully justified, ${ }^{96}$ up to a limit correlated

91 Statistics of the Colony of New Zealand for the years 1870 to 1899 [Blue Books].

92 J. D. Ritchie, 'Report of the Secretary for Agriculture and Chief Inspector of Stock', AJHR H-21 (1893).

93 [Complaints about natural enemies], 1896-98. Archives New Zealand, Wellington, R1762009.

94 Clark, The invasion of New Zealand, 266.

95 A. J. D. Tennyson, 'The origin and history of New Zealand's terrestrial vertebrates', New Zealand Journal of Ecology 34 (2010): 6-27.

96 J. C. Russell et al., 'Importance of lethal control of invasive predators for island conservation', Conservation Biology 30, no. 3 (2016): 670-2, doi.org/10.1111/cobi.12666. 
with the size and location of the island and the number of human residents. ${ }^{97}$ Such programmes on uninhabited islands - even very large ones-are now routinely successful, in part because islands offer a better chance of preventing reinvasion.

That is a completely different matter from the reactions of mainland species familiar (in the biological sense) with each other as natural predators and prey. A 'natural enemy' in this sense is the product of an evolved interaction that includes the mutually adaptive population dynamics and flexible behaviour that allow long-term coexistence at landscape scale. The impact of invasive rodents and mustelids on New Zealand's native fauna was overwhelmingly of the disastrous new-invader kind; that of ferrets on rabbits, the accommodating old-enemy kind.

Ferrets soon spread throughout the open country of both main islands of New Zealand, and, contrary to expectations, they survived the Otago winter easily in warm, dry burrows, provided there was enough food-the only conditions they cannot tolerate are being wet, cold and hungry for too long. ${ }^{98}$ But there was no sustained and widespread beneficial effect of ferret predation on the national rabbit population.

Bullen was the first to try ferrets on a large and systematic scale on his run at Kaikoura, and he was the first to find the formula required to make ferrets serve his interests rather than their own. He was successful enough to be able to suspend all other forms of rabbit control on his land. He understood, as few others did, that ferrets could affect rabbit populations only given certain conditions.

First, that rabbit numbers have to be first reduced so far as possible by other means. The quickest way of doing this was by poisoning the rabbits in winter, but the timing had to be correct to avoid the risk of ferrets eating the poisoned rabbits; otherwise they would be found dead all over the run.

Second, that ferrets must be turned out in early spring and in sufficient numbers; those liberated only a few at a time on thickly infested ground could not be expected to cope with the number and increase in rabbits.

Third, that no rabbit trappers can be employed anywhere that ferrets are working, since rabbit traps kill ferrets as well as rabbits. As one runholder reported: 'So long as we employed rabbiters, the rabbits increased'. ${ }^{99}$ Another 'tried [rabbit] trapping and caught 70 ferrets. ${ }^{100}$

97 D. R. Towns and K. G. Broome, 'From small Maria to massive Campbell: Forty years of rat eradications from New Zealand islands', New Zealand Journal of Zoology 30, no. 4 (2003): 377-98, doi.org/10.1080/03014223.200 3.9518348 .

98 Thomson, 'A history of the ferret', 471-80

99 Walter Gibson, cited in 'Report of the Joint Committee on Sheep and Rabbit Acts', AJHR I-5 (1884), 122.

100 C. J. Tully, cited in 'Report of the Joint Committee on Sheep and Rabbit Acts', AJHR I-5 (1884), 137. 
Fourth, that domestic ferrets should be trained to kill live rabbits before release into the wild.

Fifth, that owners of neighbouring properties should act together, or properties being treated should be protected by rabbit fences, so that land that has been cleared is not immediately reinvaded from adjacent uncontrolled lands.

After eight years, Bullen could report in 1881 that he had many hundreds of ferrets on his property of more than 100,000 acres. He routinely supplemented their numbers by breeding and releasing about 200 a year, and needed no other method of rabbit control. ${ }^{101}$

Contemporary research on managing rabbits ${ }^{102}$ supports Bullen's view that ferrets could potentially keep the numbers of rabbits down if they were already reduced by some other factors and if there were enough ferrets present at, or just before, the start of the rabbit breeding season. Ferrets can search burrows and kill whole litters of young rabbits before they emerge, which is an effective way of preventing an increase in numbers of adult rabbits if done intensively, but is usually not possible unless ferret numbers are supplemented in early spring. That was the strategy employed by several runholders in Marlborough. Walter Gibson summarised the method for the Joint Committee:

I purchased all the ferrets I could get and turned them out. Since then I have been working with ferrets and have been breeding a large number ... The whole of that country has been pretty well cleared of rabbits ... when fresh detachments of rabbits [arrive from higher ground] we send ferrets out. They kill all the young ones, consequently the whole country is now practically free of them ... Bullen [his neighbour] has been breeding ferrets for 10 years ... Kaikoura district was once almost ruined by rabbits ... it was quite a desert. It is now covered with grass. I shall breed 1,000 ferrets this year. ${ }^{103}$

The problem, in most other places, was that ferrets tended to be released in too small numbers, or too late in the breeding season, when the advantage of their ability to clean out whole nests of small young was already lost, or onto huge unfenced runs where hard-won local benefits were quickly reversed by unstoppable reinvasion.

101 Anon., 'Report of the Rabbit Nuisance Committee' [1880-81].

102 J. Parkes, 'Rabbits as pests in New Zealand: A summary of the issues and critical information', Contract Report LC9495/141 (Christchurch: Manaaki Whenua Landcare Research, 1995); R. P. Pech et al., 'Limits to predator regulation of rabbits in Australia: evidence from predator-removal experiments', Oecologia 89, no. 1 (1992): 102-12.

103 R. Johnson, 'Report of the Joint Committee on Sheep and Rabbit Acts'. 
So over the country as a whole, although wild ferrets left to their own devices certainly did survive and breed, and they killed a lot of rabbits, ferret numbers were and are determined by rabbit numbers rather than vice versa. ${ }^{104}$

Not everyone agreed with the runholders' assumption that the New Zealand economy would be ruined by rabbits. Sir James Hector, one of the colony's leading scientists, pointed to new economic opportunities created by the increasing international demand for rabbit skins for fur gloves and felts, and for canned or frozen rabbit meat. He predicted that much of the country would be more profitably occupied by rabbits than by sheep. ${ }^{105}$

Hector's opinion led to the obvious question: could income from rabbits compensate for loss of income from wool? The answer can be indirectly indexed from the official records of income from export of rabbits compared with wool (Figure 3).

Exports of wool, one of the colony's principal products at that time, had increased steadily until 1876 as more runs were taken up and developed, but after 1877 exports of rabbit skins began an even faster rise. The export records clearly show that the rabbit invasion shifted up a gear in 1877, and, especially in the years 187887 , it was having a severely depressing effect on the colony's income from wool production. ${ }^{106}$ An official survey listed 99 pastoral runs abandoned in Otago alone between 1877 and $1884 .{ }^{107}$ More detailed records extracted from the farm diaries of two sheep stations in the Waitaki Valley (1874-1907 at Otematata, and 1891-1930 at Hakataramea) are plotted by Holland and Figgins, ${ }^{108}$ and demonstrate the even more dramatic impact of rabbits on wool production on the local scale.

For a while, the harvesting of rabbit meat provided an alternative source of income for distressed landholders. The owners of canning factories and (after the development of refrigerated shipping) dealers in frozen carcases paid them to cease using poison when rabbits were in their prime, and by the 1890s these inducements had indeed created a valuable buffer against hard times, but at a cost: it created a corps of professional rabbit farmers who conserved the stocks and resisted effective control. ${ }^{109}$ Far from adding to the rabbit-control effort, trapping by professional rabbiters made things worse. On properties where rabbits were harvested for meat,

104 G. Norbury, R. Heyward, and J. Parkes, 'Short-term ecological effects of rabbit haemorrhagic disease in the short-tussock grasslands of the South Island, New Zealand', Wildlife Research 29, no. 6 (2002): 599-604, doi.org/10.1071/WR00085; G. Norbury and C. Jones, 'Pests controlling pests: Does predator control lead to greater European rabbit abundance in Australasia?', Mammal Review 45 (2015): 79-87, doi.org/10.1111/mam.12034.

105 Bruce Herald, 28 February 1888.

106 Statistics of the Colony of New Zealand for the years 1870 to 1899 [Blue Books].

107 J. P. Maitland, 'Runs abandoned in Otago during years 1877-84', AJHR C-09 (1885): 1-3.

108 Holland and Figgins, 'Environmental disturbance triggering infestations', 41-79.

109 J. Hall, 'Report, Minutes, Resolutions etc of the Australasian Stock Conference, Wellington, October 1892', AJHR $\mathrm{H}-2$ (1893). 
rabbit numbers greatly increased during the off season. ${ }^{110}$ Government officers attempting to enforce the Rabbit Nuisance Act regarded such cosy arrangements as illegal. Holland and Figgins ${ }^{111}$ provide a 1917 photograph of a rabbit canning factory at Alexandra, and W. T. Glasgow ${ }^{112}$ lists data on rabbit meat exports.

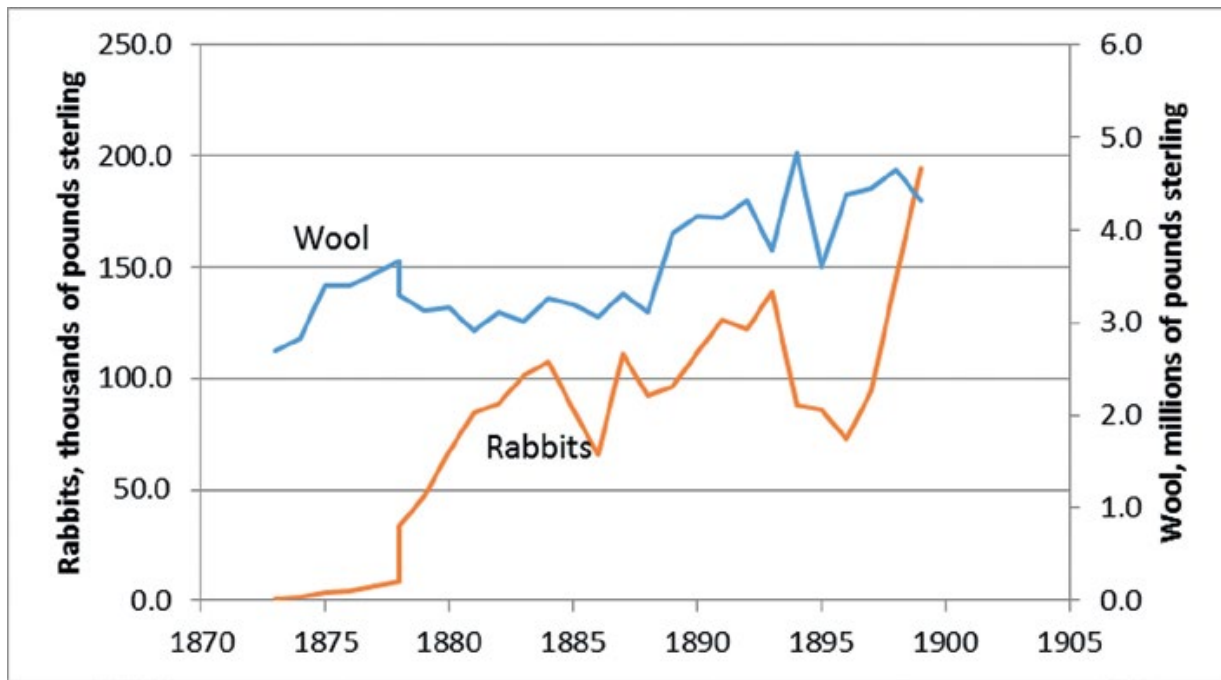

Figure 3: Comparative value in millions of pounds sterling of exports of wool, and of rabbits (in thousands), 1873-99. Income from rabbits was derived from exporting dried skins (1873-93), ${ }^{113}$ then from both skins and frozen carcases with skins on (1894-99)..$^{114}$

Source: Author's compilation of data from the references cited.

In 1949, Clark ${ }^{115}$ asked whether income from rabbits could compensate for losses from wool. The official statistics show that in 1873, wool generated an export income of $£ 2.7$ million, compared with only $£ 1,300$ from rabbit skins. The profits of the wool barons rapidly increased to $£ 3.7$ million in 1877 , when the export value of rabbits was $£ 8,600$. From 1878 to 1888 inclusive, the value of wool exports stagnated between $£ 2.9$ and $£ 3.3$ million, while the value of rabbit skins escalated to over $£ 100,000$ in those same years. Wool exports did not reach $£ 4$ million until 1889 , and even in 1899 were still only $£ 4.3$ million, but still a lot more than the $£ 195,000$ from rabbit skins and frozen meat (Figure 3).

110 J. D. Ritchie, 'Annual Report on the Rabbit Nuisance' [1891-92], AJHR H-19 (1892).

111 Holland and Figgins, 'Environmental disturbance triggering infestations', 41-79.

112 W. T. Glasgow, 'Rabbits and rabbit-skins exported, 1894-1900', AJHR H-47 (1901).

113 Statistics of the Colony of New Zealand for the years 1870 to 1899 [Blue Books].

114 Glasgow, 'Rabbits and rabbit-skins exported, 1894-1900'.

115 Clark, The invasion of New Zealand. 
In 1947 , the scientist Kazimierz Wodzicki ${ }^{116}$ tried to answer the same question, using slightly different assumptions. He reckoned that the economic value of one breeding ewe, producing about 8 pounds weight of wool and one lamb a year, was about $£ 1$ a year. His calculation of stock equivalents was based on feeding trials showing that 15 rabbits ate as much as one sheep. If so, 50 million rabbits would displace 3.33 million sheep, and thereby (after adding the costs of pasture damage and subtracting the income from rabbits exported) lead to a net loss of $£ 3$ to $£ 3.5$ million.

Estimated either way, the compensatory income from rabbits was marginal at the gross national level, though it probably saved some farmers from bankruptcy during the leanest years. More importantly, such naïve calculations do not account for the many other financial burdens imposed on runholders by a heavy rabbit infestationsoil erosion, irreversible pasture destruction, poor-quality sheep producing less wool and fewer lambs, and the huge costs of attempting to manage the rabbits. Rough and variable though these figures undoubtedly are, they hardly support the government's early confidence that ferrets would be the salvation of the pastoral industry. ${ }^{117}$

Long before the end of the nineteenth century, ferrets were well established in the wild and breeding freely. They and all other predators of rabbits were still legally protected until 1903, in the hope they might yet turn the scales against the rabbit pest, but then an amendment to the Rabbit Nuisance Act 1882 partially removed that protection. ${ }^{118}$ Now, ferrets themselves are a declared noxious species, subject to control campaigns even though ferret numbers are more likely to be determined by rabbit numbers than by human action, especially in the semi-arid pastoral lands where they were first released. ${ }^{119}$

By 1890 , the colonial government had accepted that New Zealand's first experiment in biological control had been a regrettable failure. Later commentators were more forthright: Herbert Guthrie-Smith ${ }^{120}$ reported that the strength of local feeling in Hawke's Bay against those who introduced first the rabbits and then the mustelids could be judged from the resolution passed 'with ferocious unanimity' to put a bounty of a guinea a head ( $£ 11$ s, or about NZ $\$ 88$ in today's money) on every mustelid caught dead or alive. But he was also a realist: he added sadly that '[n]o paper resolutions, however, can stay a plague once introduced; harm of this sort done cannot be undone'.

116 K. Wodzicki, 'Interim report on wildlife problems in New Zealand' (Wellington: Department of Scientific and Industrial Research, 1947)

117 Anon., 'Report of the Rabbit Nuisance Committee' [1880-81], 17.

118 P. Wells, 'The Fall and Fall in the Legal Status of Mustelids in New Zealand', Environment and History 15, no. 3 (2009): 343-68, doi.org/10.3197/096734009X12474738225593.

119 B. K. Clapperton and A. E. Byrom, 'Feral ferret', in Handbook of New Zealand Mammals, 2nd ed., ed. C. M. King (Melbourne: Oxford University Press, 2005), 294-307.

120 H. Guthrie-Smith, Tutira: The Story of a New Zealand Sheep Station, 4th ed. (Wellington: A. H. \& A. W. Reed, 1969), 354. 


\section{Discussion}

Many critics at the time and since have blamed the early runholders for altering the natural environment of the southern pastoral grasslands in favour of rabbits, by overstocking, repeated burning and creating refuge areas in railway embankments, sod walls and under rampant gorse hedges, and for the holding by absentee landlords of huge hill country runs where labour-intensive rabbit control was impossible. In reassessing this argument, the environmental historian Robert Peden ${ }^{121}$ pointed out that uninhabited island ecosystems could be wrecked by rabbits just as well; Peden and Holland ${ }^{122}$ reviewed recent evidence that burning did not destroy native vegetation wholesale; and Holland and Figgins ${ }^{123}$ emphasised that local variation in soil and climate strongly modified the impact of rabbit damage.

Arguments about the proper management of leasehold land in the semi-arid, rabbitprone high country have continued to the present. Thanks to the 1997 introduction of rabbit calicivirus disease, rabbit numbers are at present temporarily reduced, but they are expected to recover as immunity spreads. As rabbit numbers increase again, more properties are finding that the costs of rabbit control exceed the income gained, reviving old arguments about the use of aerial baiting against rabbits with carrots poisoned with the pesticide $1080 .{ }^{124}$ Fortunately, in most of the rest of the country, contemporary habitats are less favourable to rabbits than the semi-arid lands, and predation upon rabbit populations already influenced by other factors is now counted as among the reasons rabbits are no longer the pest they once were. ${ }^{125}$ But eradication was impossible, and at present it still is.

\section{Why ferrets failed to control rabbits}

Biological control can be defined as a direct human manipulation of one species (an agent or natural enemy) in order to achieve an impact on another species (a pest). A successful operation of this kind requires certain system conditions, primarily that predator and prey should have matching population dynamics, dispersal capabilities and operational areas. ${ }^{126}$ If these conditions can be met, the specific characters of the imported agent will determine the details of the outcome. For example, in 1887 Californian citrus orchards were almost ruined by the cottony

121 Peden, Making Sheep Country.

122 R. Peden and P. Holland, 'Settlers transforming the open country', in Making a New Land, ed. E. Pawson and

T. Brooking (Dunedin: Otago University Press, 2013), 89-105.

123 Holland and Figgins, 'Environmental disturbance triggering infestations', 41-79.

124 G. Nugent et al., 'Why $0.02 \%$ ? A review of the basis for current practice in aerial 1080 baiting for rabbits in New Zealand', Wildlife Research 39 (2012): 89-103, doi.org/10.1071/WR11121.

125 Norbury and Reddiex, 'European rabbit', 131-50.

126 Norbury and Jones, 'Pests controlling pests: Does predator control lead to greater European rabbit abundance in Australasia?', 79-87. 
cushion scale insect Icerya purchasi. ${ }^{127}$ Within a year of the 1888 introduction of vedalia beetles (ladybirds: Rodolia cardinalis), both species were reduced to small numbers of individuals playing cat and mouse among the orchards. In that same year of 1888, stoats and weasels were being imported into New Zealand at the rate of more than 1,000 a year ${ }^{128}$ and organised breeding of ferrets was producing offspring for release by the tens of thousands, ${ }^{129}$ but no such immediate effect on rabbits was achieved. New Zealand authorities may not have known of the startling success of ladybirds in California, but even if they did, the biological differences between vertebrate and invertebrate predators would have made any hopeful comparison with their own action quite invalid.

The differences between ladybirds and ferrets as biological control agents are stark. Ladybirds can match or exceed the reproductive and dispersal rates of scale insects; their aerial searching and wide dispersal are rapid and efficient; they can kill without risk and have few other prey as attractive; scale insects clump together, and have no defences except high fertility, so every individual found by a ladybird is at risk; when ladybirds are surrounded by more scale insects than they can eat, they simply produce more ladybirds, allowing the prey minimum recovery time. Ferrets cannot match the breeding rate or running speed of rabbits; their underground searching is comparatively slow and inefficient and they disperse slowly on foot; rabbits can hide in and escape from complex burrow systems, and rapidly reinvade a cleared area; they are alert and can fight back, so are risky for a ferret to kill compared with other equally acceptable native prey, including lizards and flightless birds; wild ferrets stop to eat after killing one grown rabbit or a nest of infants, and resume hunting only when necessary-the rabbits are left to multiply while the ferrets rest rather than produce more ferrets.

So, most important, ladybirds and ferrets do not both have the attributes required to ensure their predatory effects match increases in the target populations. Ladybirds do this naturally, but ferrets can do it only with local and temporary human assistance, as Bullen discovered by supplementing ferret populations shortly before and during the rabbit's breeding season in spring, and protecting them by prohibiting rabbit trapping.

The arguments for the wholesale releases of mustelids that impressed the nineteenthcentury colonial government are well preserved and worth careful attention, because they explain why events unfolded as they did, in the terms and language understood at the time. The interests and convictions of the players explain much of the story,

127 L. E. Caltagirone and R. L. Doutt, 'The history of the vedalia beetle importation to California and its impact on the development of biological control', Annual Review of Entomology 34 (1989): 1-16, doi.org/10.1146/ annurev.en.34.010189.000245.

128 Statistics of the Colony of New Zealand for the years 1870 to 1899 [Blue Books].

129 Stock Department, 'The supply of ferrets (contracts made by Stock Department)'. 
and so the story itself cannot be fully understood without paying attention to them. In particular, they explain why the successful early strategy developed by Bullen was used to justify the later indiscriminate releases by others, who were desperate enough to ignore the essential conditions Bullen had emphasised. Later experience amply confirmed that too few ferrets hunting individual rabbits year-round cannot affect rabbit populations, mainly because ferrets could never remove rabbits faster than they could be replaced.

No one expressed the unequal odds of the human battle against rabbits better than the philologist, poet and amateur botanist Arnold Wall, writing in the 1920s:

Where the sheep feed, there feed I, / Depleted lands behind me lie, / Of dogs and guns I take no heed, / I only breed and breed and breed.

At traps and guns and dogs I smile, / I laugh at cats' and weasels' guile, / I frolic, nibble, frisk and feed, / But all the time I breed and breed.

They send my skin to clever folks, / who turn me into sealskin cloaks, / A sorely hunted life I lead, / But still I breed and breed and breed.

When foes attack I cannot bite, / I have no spirit for a fight, / By other methods I succeed, / I merely breed and breed and breed. ${ }^{130}$

\section{Tame versus wicked problems of managing invasive species}

The successful establishment and spread of ferrets in New Zealand qualifies them as invasive, that is, an introduced species that is successful in colonising large areas and reaching high numbers. ${ }^{131}$ The problems arising from the management of invasive species are among the prime challenges to conservation authorities worldwide, which D. J. Woodford et al. ${ }^{132}$ usefully distinguished as either 'tame' or 'wicked' problems. They defined tame problems as those with simple or obvious solutions, whereas wicked problems are those for which complete solutions are difficult or impossible to find, largely because of intense conflicts of interest among the major stakeholders. As an example of a wicked conservation problem, Woodford et al. analyse the arguments between anglers and conservationists surrounding the management of rainbow trout in New Zealand.

130 A. Wall, 'A song of Brer Rabbit of Otago', in Out of Town. Writing from the New Zealand Countryside, ed. J. Gordon (Christchurch: Shoal Bay Press, 1999), 189. The original poem, first published in 1922, has three more verses, the last recommending that nations aiming to attain global leadership should do the same.

131 D. W. Macdonald, C. M. King, and R. Strachan, 'Introduced species and the line between biodiversity conservation and naturalistic eugenics', in Key Topics in Conservation Biology, ed. D. W. Macdonald and K. Service (Oxford: Blackwell, 2007), 186-205.

132 D. J. Woodford et al., 'Confronting the wicked problem of managing biological invasions', NeoBiota 31 (2016): 63-86, doi.org/10.3897/neobiota.31.10038. 
The tragedy enacted by Bayly and his colleagues in the nineteenth century is that they saw the long struggle against rabbits as a tame problem: the simple and obvious solution was to bring in natural enemies, starting with ferrets. The conflicting interests of the time, between wool growers and their opponents summarised above, made the issue a wicked problem, but it was simply not possible to understand or solve it then.

\section{Conclusions}

The people whose personal and financial interests were most affected by the rabbits were more often the absentee leaseholders of large pastoral runs in the backcountry rather than the smaller-scale farmers who knew and closely managed their own land. These same leaseholders held disproportionate influence over colonial policy through their social connections and their majority membership in the Legislative Council. They were all strongly in favour of importing the natural enemy of the rabbit for release on the backcountry, as opposed to the far more expensive and labour-intensive manual methods of rabbit control that could be effective in more closely settled districts. In particular, they found that employing professional rabbiters merely encouraged the sustained harvesting of rabbits. 'If you want to breed rabbits keep rabbiters', said one. ${ }^{133}$

Chief Inspector Bayly was the public servant with most influence over anti-rabbit policy through the 1880s. Bayly pursued his strategy of importing natural enemies against frequent protests from those who did not agree with his view that the risk to native birds was a price worth paying for saving the wool industry.

Serious attempts by private individuals to import ferrets were under way for at least eight to 10 years before the government actively supported and extended them. Some, such as Bullen of Kaikoura, showed that under certain conditions ferrets could have a significant short-term effect on the numbers of rabbits by landscape-scale acceleration of juvenile mortality. These conditions were met when wild populations of ferrets were supplemented with thousands of locally bred ferrets turned out at the start of the rabbit breeding season, protected from rabbit trappers, and reinvading rabbits kept out by fencing. Because Bullen had direct control of his own land, that is, he did not have to compromise with other stakeholders, his situation was close to Woodford et al.'s definition of a tame problem. Outside these conditions, where no such constraints limited the independent actions of multiple players in an intensely controversial game, the problem of saving the wool industry became intractably wicked, and indiscriminate mass release of tens of thousands of ferrets had no effect on rabbit numbers.

133 R. Johnson, 'Report of the Joint Committee on Sheep and Rabbit Acts', 247. 
Tempting though it may be, it is inappropriate to use twenty-first-century knowledge to criticise decisions made by the colonial government. On the contrary, their experience has illustrated some valuable principles of pest management applicable today. Ambitious strategies for managing invasive pests (rats, mustelids and Australian brushtail possums) are now being developed in New Zealand, ${ }^{134}$ informed by long experience of past campaigns, including those against rabbits. Managing pest populations by lethal means (what the ecologist Graeme Caughley ${ }^{135}$ called 'frontal assault') has a long history, and developments in more and better ways of killing individual pests are advancing rapidly. These new methods can prevent short-term damage to threatened species, and are important despite their drawbacks ${ }^{136}$ because they can buy us time to find something better. But pest populations are determined by the dynamic balance between the numbers input (fertility, immigration) versus output (mortality, emigration), all of which are locally and seasonally variable. As Bullen demonstrated so clearly, the most effective lethal methods are those that are accompanied by some means of reducing fertility in the remaining pest population. So the task of protecting the most critically threatened remaining native fauna long-term is a definitely not a tame problem.

The history of rabbits and ferrets in New Zealand is important to understand because it illustrates the consequences of mistaking a wicked problem for a tame one. A stable future pest-management policy must depend on interactions between finding new ways of culling the most pervasive pest populations and managing the reproductive capability of the remainder, in both cases by using techniques operable at landscape scale and by socially acceptable means. Finding new ways of increasing mortality, such as by moving beyond the effective but controversial aerial distribution of 1080 poison, ${ }^{137}$ and reducing fertility, such as by genetic manipulation of the sex ratio of offspring, ${ }^{138}$ are under active investigation. Both will take much longer than simple damage prevention, because they are part of a wicked problem, whose solution depends not only on technical expertise but also on widespread social approval and collaboration, but the will to succeed is there. ${ }^{139}$ George Bullen would be impressed.

134 B. Owens, 'Behind New Zealand's wild plan to purge all pests', Nature 541 (2017): 148-50, doi. org/10.1038/541148a; J. C. Russell et al., 'Predator-Free New Zealand: Conservation Country', BioScience 65 (2015): 520-5, doi.org/10.1093/biosci/biv012.

135 G. Caughley, Analysis of vertebrate populations (London: John Wiley \& Sons, 1977).

136 D. M. Tompkins and C. J. Veltman, 'Unexpected consequences of vertebrate pest control: Predictions from a four-species community model', Ecological Applications 16, no. 3 (2006): 1050-61, doi.org/10.1890/10510761(2006)016[1050:UCOVPC]2.0.CO;2.

137 Nugent et al., 'Why 0.02\%?', 89-103.

138 Russell et al., 'Predator-Free New Zealand: Conservation Country', 520-25.

139 Owens, 'The Big Cull', 148-50. 


\section{Acknowledgements}

This project would have been impossible without the help of many people, especially Ken Ayers, who did much of the early archival searching both in New Zealand and in the UK. Librarians: Judith Holloway (Hocken Collections, Dunedin), Cheryl Ward (Waikato University), Emma Knowles (Toitū Otago Settlers Museum, Dunedin), Keith Giles (Auckland Central City Library), Rachael Gardner and Marion Lowman (Bodleian Library, Oxford) and staff at Cambridge University Library and the library of the Zoological Society of London. Archivists: Chris Meech (Waitaki District Archive), Katherine C’Ailceta, Donal Raethel (Archives New Zealand, Wellington), Kas McEntyre (Alexandra), Rebecca Smith, Sonya Johnson (Invercargill), Anne Maguire (Arrowtown), Fiona Passi (Auckland), many staff at the National Archives (Kew), National Maritime Museum (Greenwich), Berkshire Record Office and Museum of English Rural Life (both Reading). Information: Ken Ayers, Dawn Coburn, Peter Holland, Frank Leckie, Rachel Letofsky, Fay McDonald, Tessa Mills and Evan Tosh. Graphics: Max Oulton and Conrad Pilditch. Hospitality: Daphne and Bill Lee (Dunedin), Anne Sudell, Jeff and Kate Booth (Wellington), Wolfson College (Cambridge) and Lauren Harrington (Oxford). Funding: University of Waikato RTCF Grant 2016/104615. Helpful comments on early drafts: Ken Ayers, James Beattie, Tony Beauchamp, Tom Brooking, Peter Holland, Grant Norbury, Roger Pech and Evan Tosh. 
This text is taken from International Review of Environmental History, Volume 3, Issue 1, 2017, edited by James Beattie, published 2017 by ANU Press, The Australian National University, Canberra, Australia. 